\title{
CONSTRUCTING ADAPTIVE ECOLOGIES: TOWARDS A BEHAVIOURAL MODEL FOR ARCHITECTURE
}

\author{
A B S T R A C T
}

György Kepes once proclaimed, 'In our new conceptual models of nature, the stable, solid world of substance, which in the past was considered permanent and preordained, is understood as widely dispersed fields of dynamic energies. Matter - the tangible, visible, stable substance in the old image of the physical world - is recast today as an invisible web of nuclear events with orbiting electrons jumping from orbit to orbit." The fixed and finite tendencies that once served to categorise the natural and the man-made worlds have been rendered obsolete.

Today the intersections of information, life and matter display complexities that suggest the possibility of a much deeper synthesis. Within this context, however, architecture is being forced to radically refactor its response to new social and cultural challenges and an accelerated process of urbanisation. Architecture today must participate and engage with the information-rich environments that are shaping our lives by constructing computational frameworks that will allow for change, embracing a demand for adaptive models for living. Our approach to addressing these challenges explores a systemic form of interaction that engages behavioural features that are polyscalar, allowing biodiverse networks to operate between urban contexts, buildings and materials. An intimate correlation of material and computational interaction allows for the emergence of a generative timebased behavioural model of living, where the interplay of local agency and environmental stimulus constructs collective orders. Unlike most manmade structures, the architectures of these structures are not embedded in a blueprint, but rather are correlated operations governed through emerging collective interaction. 
For over a decade, the AA Design Research Laboratory (AADRL) has been organized as an open-source experimental design studio dedicated to the systematic exploration of generative design systems and discourses within architecture and urbanism. The work of the laboratory has actively examined processes to capture, control and shape a continuous flow of information across today's rapidly evolving computational and communication frameworks. Within the laboratory generative computational methods from behavioral, parametric and material form finding processes are hybridized creating work flows that actively engage a digital/analogue feedback. It is with this spirit that within my studio at the Design Research Lab that we have pursued a research that has explored models of behavioral examining the role of the singular within the collective. Our aim has been to speculate on systems that could communicate between urban, building, and material scales of operation. The city understood as a behavioral ecology that motivates our systems through feedback and negotiation between material presence and behavioral response. The research explores a new nature that combines the biological and computational as an adaptive and evolving organism.

\section{A CYBERNETIC APPROACH}

In September 1969 a landmark issue of Architectural Design, guest-edited by Roy Landau, brought issues of interaction and digital computation into mainstream architectural media for the first time. Alongside articles by Nicholas Negroponte, Cedric Price and Warren Brodey, the issue featured an essay by the cybernetician Gordon Pask, who introduced the idea that 'architects are first and foremost system designers who have been forced to take an increasing interest in the organisational system properties of development, communication and control'. ${ }^{1}$ Architecture, Pask argued, had no theory to cope with the pressing complexities of the time, and it was only through a cybernetic understanding of systemic processes that the discipline would evolve. Central to Pask's argument was an understanding of the world through the pursuit of 'communication and control' and the elucidation of what he termed 'aesthetically potent environments' - external spaces designed to foster pleasurable interactions. These interactions were to be framed through a commitment to novelty. 'Man', he wrote, 'is prone to seek novelty in his environment and, having found a novel situation, to learn how to control it'. ${ }^{2}$

In his foreword to John Frazer's seminal book An Evolutionary Architecture (1980), Pask presents a fundamental cybernetic thesis that 'architecture is a living, evolving thing'. In a way this is evident. Our culture's striving towards 


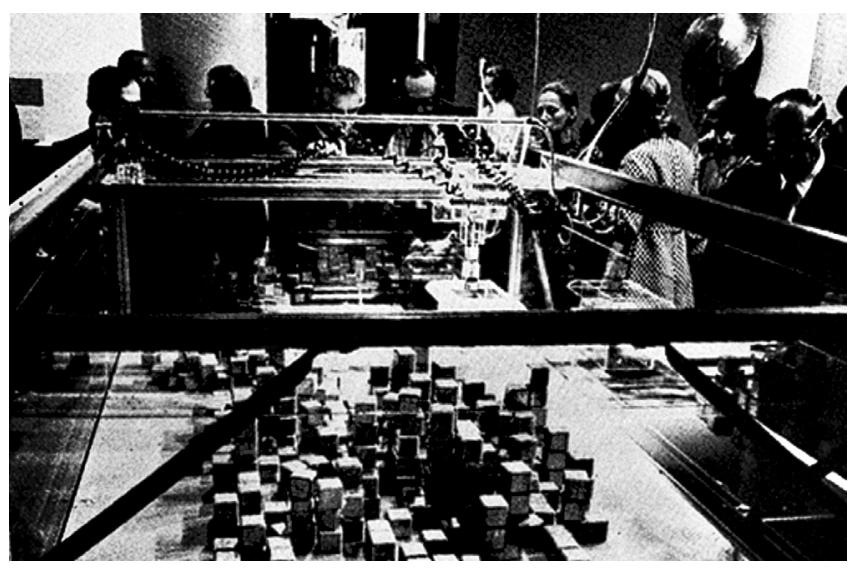

Figure 01. Nicholas Negroponte (AMG), Seek at the Jewish Museum in New York, 1970. The Architecture Machine Group led by Nicholas Negroponte produced Seek, a computer-controlled environment inhabited by gerbils as part of Jack Burnham's 1970 'Software' show in New York. SEEK, (C) Nicholas Negroponte, Soft Architecture Machines.

Seek is potentially the most radical of all proposals developed by the AMG, as it constructs an environment that embeds live agents (gerbils), scanning arm systems and building blocks in an evolving fitness landscape. The experiment is set in motion when the gerbils are placed in the container and begin the process of appropriating their new environment. The gerbils' activities continually reorganize the initial block deployment, pushing and pulling blocks into new configurations. After a period of inhabitation the container becomes a display of the negotiated space of interaction through its newly formed configuration. The gerbils, blocks and scanning arm have reached a balanced negotiation through the allowance of a co-evolutionary process of becoming.

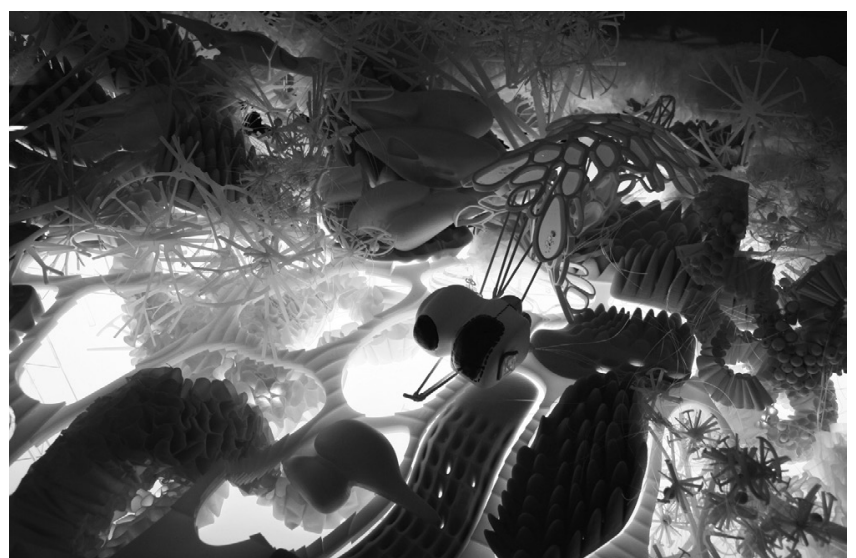

Figure 02. Minimaforms 'Archigram revisited highlights time-based protosystems that demonstrate animalistic and collective orders of organisation. Units evolve self-structured shells articulated through taxonomy of skeletal spicules. These spicules allow for complex interlinking that affords variable structuring of unit-tounit relations. From discrete self-contained units the project evolves as interactive agents that are co-dependent.

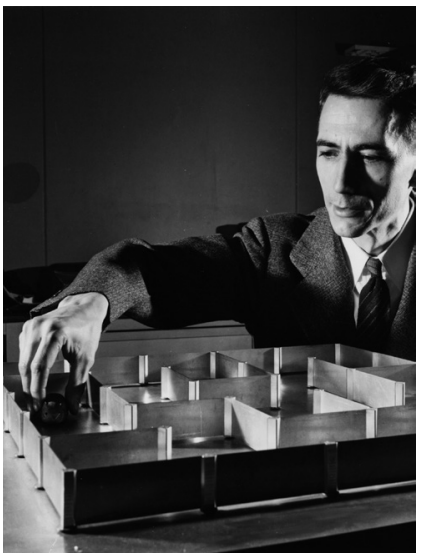

Figure 03. Claude Shannon and experimental mouse maze constructed to demonstrate machine learning, c 1952 Courtesy the Computer History Museum, Mountain View, CA. 
civilisation is manifested in the places, houses and cities that it creates. As well as providing a protective carapace, these structures also carry symbolic value, and can be seen as being continuous with and emerging from the life of those who inhabit the built environment. It is appropriate to stress an important cybernetic feature of the work; namely that unity is not uniformity, but is coherence and diversity admixed in collusion. ${ }^{3}$ In the work of Gordon Pask and other artists and scientists, the use of cybernetic methods resulted in new experiential forms of practice. ${ }^{4}$ As telematic artist Roy Ascott notes, cybernetics has transformed our world by 'presenting us with qualities of experience and modes of perception which radically alter our conception of it'. ${ }^{5}$ In addition, the second order cybernetician Ranulph Glanville has argued that cybernetics constructs a new way of thinking about the material world: 'the knowledge we previously had from science was all about trying to remove the observer so we could talk about an artefactual world full of things, but it is very difficult to argue about a world that exists without our sensing it' ${ }^{6}$ Glanville emphasises the role of the active observer and the distinctions to be made between science and design. In design he sees a cybernetic process at work - a form of conversational interaction. For Glanville designers 'are not observers of the world, but observers in the world'. ${ }^{7}$ Therefore, design as an activity should not limit itself solely to descriptive forms but rather use casual and circular relationships to identify generative qualities that will continuously redefine and evolve the design system itself. This is a process of continual formation rather than a state of fixed form.

\section{BEHAVIOURAL MACHINES:}

\section{SINGULAR VS COLLECTIVE AGENCY}

The dynamic and adaptive approach advocated by this publication is not one of form but of correlated formations - a model of collective living that addresses the spatial complexities of the city. A synthesis of material and computational interaction constructs a generative organisation of space and structure that explores a behaviour-based model of living through patterns found in nature.

Many of the most striking (pattern) examples that we encounter around us are evidently the products of human hands and minds - they are patterns shaped with intelligence and purpose, constructed by design. Phillip Ball ${ }^{8}$

System-to-system interactions identified through simple rule-based protocols can collectively exhibit complex non-linear behaviour. The magnitude of 
these interactions is explored across varied scales to test the potential of self-structuring orders constructed through the interplay of local agency and environmental stimulus. Early analogue cybernetic experiments - such as Gordon Pask's Colloquy of Mobiles - address the significance of parameters dealing with the observer in order to understand our tendency to attribute lifelike properties through simple, relational agent interaction.

As a result, embodied patterns emerge through goal-oriented systems that exhibit life-like characteristics. These social orders allow a synthetic interplay to construct a new breed of proto-animalistic architectures that evolve through negotiated interactions, creating a fusion of digital and analogue computation that draws on the pioneering work of the renowned neurophysiologist $\mathrm{W}$. Grey Walter. An interest in cognitive operations and biological systems led Walter to develop his machinae speculatrices (machines that watch) autonomous robots that could demonstrate how simple organisms exhibit non-linear interactions. The first of these were named Elsie and Elmer, and they took the form of phototropic tortoises inspired by a character in Lewis Carroll's Alice in Wonderland. Designed with a primitive nervous system, the tortoises constructed social action and self-organisational patterns that were characteristic of animal behaviour and ritual. Walter's genius lay in his ability to recognise complex adaptive behaviours in simple interconnected systems that focused on goal orientation and adaptation through learning. This allowed the robots to be free-ranging autodidacts that built up intelligence through interaction.

After completing his experiments with the tortoises, Walter wrote in The Living Brain (1953) that there was a 'well-defined difference between the magical and the scientific imitation of life. The former copies external appearances; the latter is concerned with performance and behaviour. Until the scientific era, what seemed most alive to people was what most looked like a living being. The vitality accorded to an object was a function primarily of its form.' Through a fusion of synthetic and natural systems, architecture can construct machines that are generative, evolving relationships that couple new forms of spatial organisation with fabrication. The ability to shift preoccupations from object to system allows our built environment to play an active and participatory role in the construction of adaptive forms through feedback.

\section{FROM OBJECT TO SYSTEM}

Gygöry Kepes states in his introduction to The Nature and Art of Motion (1965) that 'to structure our chaotic physical and social environment as well as our 

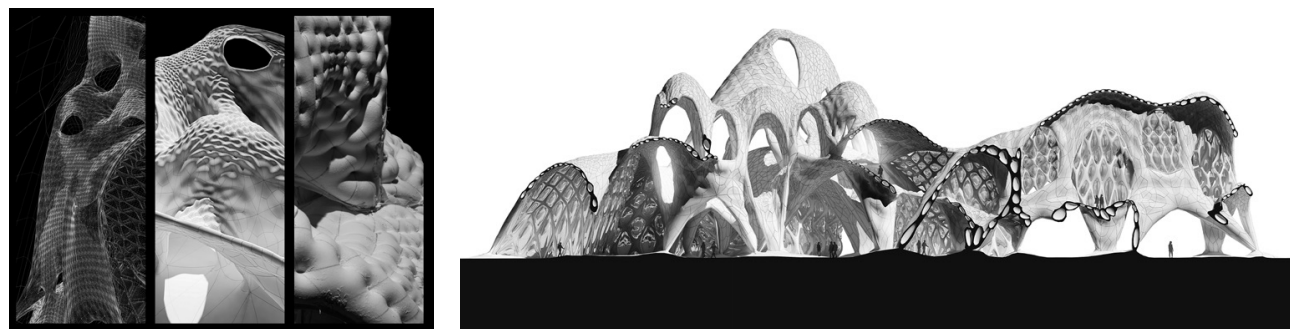

Fi gure 04. Team: Ctrl + M. Students: Claudia Ernst (Germany), Manuel Jiminez Garcia (Spain), Roberto Garcia (Spain), Stella Dourtmes (Greece). Tutor: Theodore Spyropoulos.

This research investigates a prototypical system of analogue and digital patterning of soft textile formwork. Through advanced simulation complex organizations of phase change and material computation are enabled.

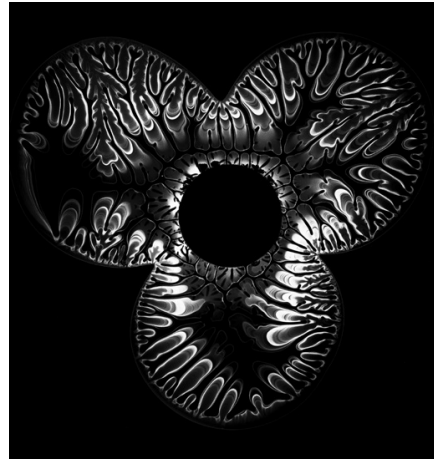

Figure 06. Team: Egloo. AADRL. Tutor: Theodore Spyropoulos. Students: Pankaj Chaudhary, Jwalant Mahadevwala, Mateo Riestra, Drago Vodanovic. Surface Tension / Hele-Shaw Cell Examining properties of the cohesive forces of surface tension, viscous fluids are placed between two pressurized parallel plates demonstrating properties of connective micro-flows.

Egloo proposes a decentralized connective neighbourhood model developed through the interplay and trans-coding of material and digital computation.

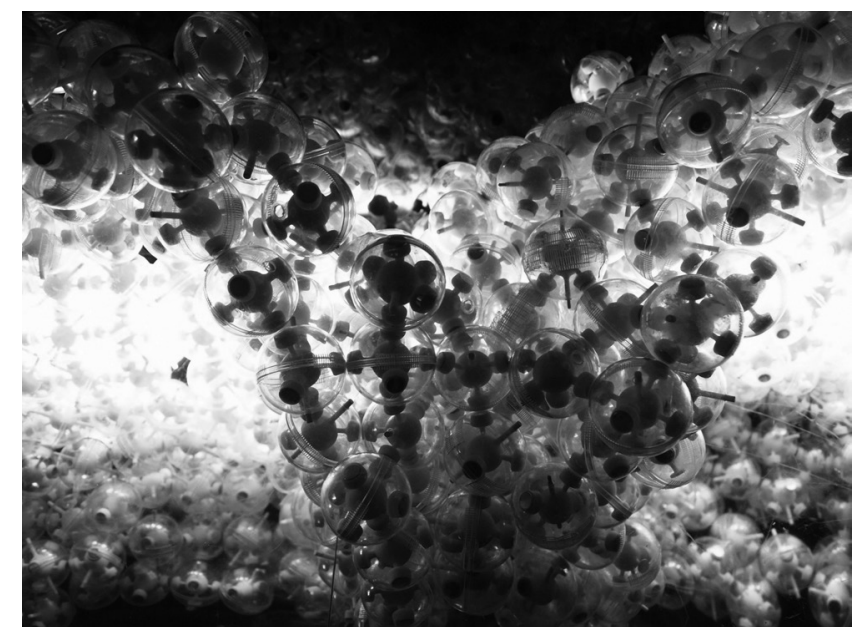

Fi gure 05. Team: rub-a-dub. Students: Sebastian Andia (Argentina), Rodrigo Chain (Colombia), Apostolos Despotidis (Greece), Thomas T. Jensen (Denmark). Tutor: Theodore Spyropoulos.

This research focuses on two areas - organizational behaviour and material behaviour. Our organizational principles operate through bottom-up logics for the assemblage and reconfiguration between one and more parts, pushing for a self-organizational self-assembled prototype. Material behaviour explores the possibilities of rearranging matter through implicit forces. As such, the focus of the project is on the idea of behaviour embedded in matter that allows for a constant reconfiguration of a global formation. 


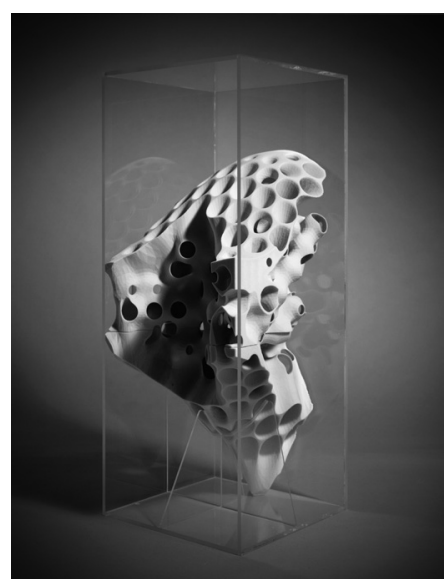

Figure 07. Team: Farm. AADRL. Tutor: Theodore Spyropoulos. Students: Marga Busquets, Sebastien Delagrange, Iain Maxwell.

Stigmergic behaviour is demonstrated in eusocial creatures that construct their complex habitations through simple decentralised rule sets. A network of complex relations built up through the use of pheromones creates an adaptive model of agent-based communication.

FARM's research explores stigmergy as pheromone based interaction ecology of agents created to generate highly differentiated and interconnected architectural typologies. Image of prototypical section developed for the Hudson Yards West Development in New York.
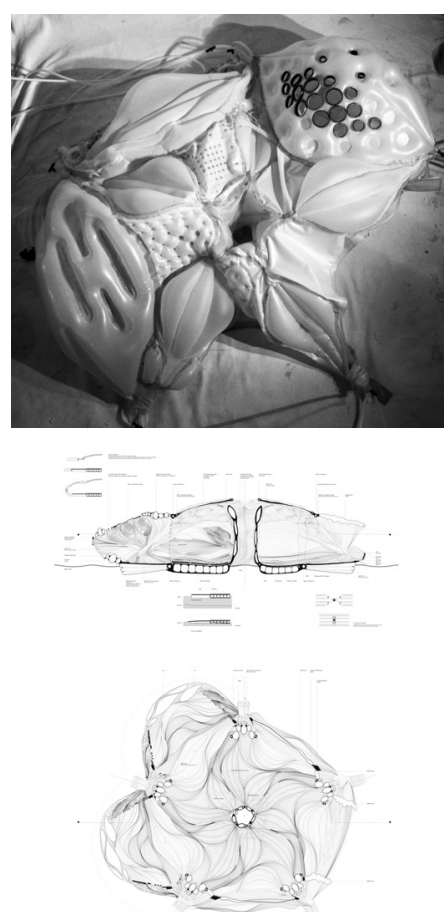

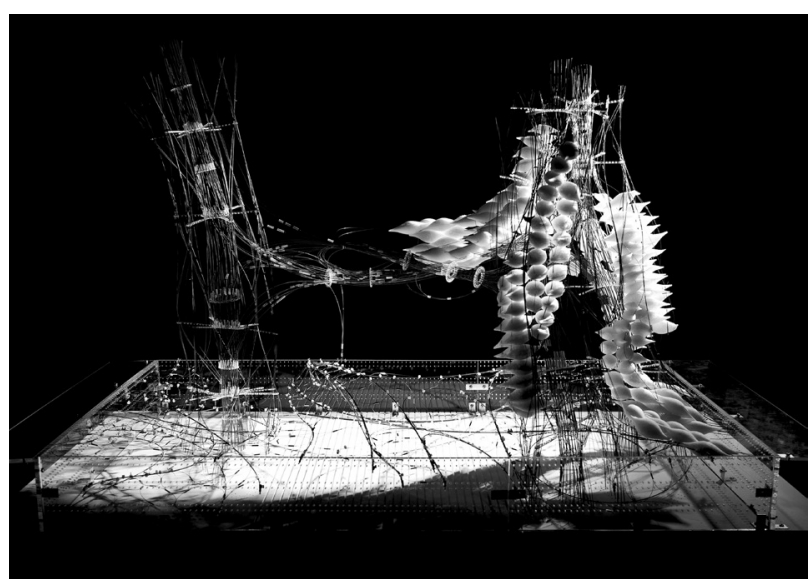

Figure 08. Team: Shampoo. AADRL. Tutor: Theodore Spyropoulos. Students: Pavlos Fereos, Konstantinos Grigoriadis, Alexander Robles Palacio, Irene Shamma.

Hair / Optimised Detour Networks - One of the seminal analogue computational experiments developed by Frei Otto and his researchers at the Stuttgart Institute for Lightweight Structures used a radial apparatus of slack wet wool strands to demonstrate that the fusion of threads would result in the overall length of the path system being reduced.

Prototype exploring a detailed development of fibre based structure system and unit deployment.

Coral growth principle (increase growth rate at areas of high curvature) informs the distribution and positioning of the housing units within the proposed network.

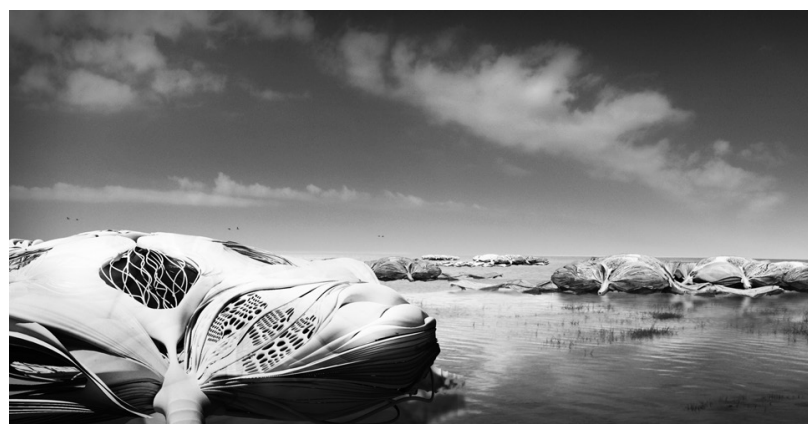

Figure 09. Team: So_Proto. Students: Miguel Miranda (Puerto Rico), Said Fahim Mohammadi (Germany), Katharina Penner (Germany), Yifan Zhang (China). Tutor: Theodore Spyropoulos.

The research aimed for the creation of soft-body architecture - architecture designed to challenge the notion of rigidity and motionlessness. In defining soft as the in-between line, linking static and dynamic, solid and liquid, it is the constant shifting of this line that a soft-body is found. An important characteristic of a soft architecture is the creation of a soft inhabitable space capable of 'moving', merging and combining - as a first step towards creating a larger life-like organization with the capacity to structure a flexible space that adapts over time to environmental changes. Through both material distribution and geometrical setup the intention is to achieve a time-based, reconfigurable architecture. Soft-body architecture exists to provide a life-like organism, a body capable of absorbing, adjusting and reconfiguring itself to a condition without losing its internal equilibrium - an ecology, unstable and stable, capable of containing the everyday changes in human nature and life. 
knowledge and values, we have to accept the conditions of the new scale and learn to use the tools that have grown from it'. ${ }^{9}$ New sensibilities have evolved in relation to communication through mediated and remote interaction, which are now critical to a research that explores the role of space and in particular the ways that the physical and public environment can communicate as an active agent. As Kepes's Bauhaus mentor and colleague László Moholy-Nagy once observed, 'design is not a profession but an attitude [...] thinking in complex relationships' ${ }^{10}$ Today, the role of science and technology offers architecture some of the most radical and thought-provoking scenarios if approached in a manner that enables participatory and collective emergence.

In the 1964 article titled 'The Construction of Change', Roy Ascott attempted to outline the terms for engaging art as a system based on the interrelations between artist, audience and environment. ${ }^{11}$ His proposal stemmed from his belief that "cybernetics was the science of behaviour and art was essentially behaviourist'. Through the interaction of these constituents, one could construct an environment in which new models of practice foreground participation, allowing aspects of play to evolve and thus creating new forms of knowledge. Ascott elaborated this idea further in his 1967 manifesto, Behaviourables and Futuribles, noting 'when art is a form of behaviour, software predominates over hardware in the creative sphere. Process replaces product in importance, just as system supersedes structure.' He went on to reinforce this sentiment by emphasising the importance of the societal and cultural: 'for a culture to survive it needs internal acrimony (irritation), reciprocity (feedbacks) and variety (change)'. In this way, the coupling of design and technology could bring about a discourse that was social and optimistic, buoyed by the shared belief that, through innovation, new channels of communication would emerge that would interconnect previously self-contained and isolated fields. Art and design was therefore seen as a tool enabling active collaboration with cultural and scientific disciplines.

We can communicate - that is, combine and reinforce our knowledge with that of other men - by stimulating the circulation of ideas and feelings, finding channels of communication that can interconnect our disciplines and enable us to see our world as a connective whole. György Kepes ${ }^{12}$

\section{ARCHITECTURE MUST PARTICIPATE}

György Kepes once wrote that 'The dynamic unity of constancy and change has a fundamental role in our intellectual growth. Our clearest understanding of the 
nature of these complementary opposites has been reached through grasp of the principle of self-regulating systems.' Similarly, our own systemic approach seeks to evolve research into new forms of living and the structuring of human environments. Experimenting through explicit models of interactions, observable patterns and proto-animalistic agency, the work within this book explores the capacity for design systems to evolve architectural elements with the capacity to self-structure, respond and evolve. In the process, and beyond deterministic methods of structuring space, issues of duration and populations evolve into a new language of assemblies as collective structures.

Today, with greater opportunities and easier access to information, comes the challenge to re-evaluate the conception and production of architecture. These enabled communication networks have fostered the possibilities for a shared and collective project - one that is not only available to all, but affords a deeper understanding of the world and our participation in it. In engaging with this shared project, it is important to recognise early experiments within this domain, such as those explored by Nicholas Negroponte and the Architecture Machine Group at MIT, which dealt with the intimate association of man and machine within architecture, and of Cedric Price, who in collaboration with Joan Littlewood and Gordon Pask designed a Fun Palace that would operate as a time-based architectural machine adapting and evolving through its everyday use. These projects provided a model for the coupling of design and technology while calling for a discourse that is both social and optimistic. Taken together, architecture and design can be seen as a tool that enables an active collaboration within cultural and scientific disciplines. Though not a new pursuit in architecture, it should be recognised that we have greater access to a collective understanding than ever before.

Design should be progressive and challenge people. We should be enabling a diverse set of questions about how we live and the role that architecture can play in our everyday lives. As John Frazer has reminded us, "perhaps computing without computers is the most important lesson to be learned by designing these tools. The real benefits are found in having to rethink explicitly and clearly the way in which we habitually do things.' Architecture today can serve as an emergent framework that displays a new nature, combining the biological, social and computational in an adaptive and evolving organism, reasserting Karl Friedrich Schinkel's belief that 'architecture is the continuation of nature in her constructive activity'. 
Gordon Pask, "The Architectural Relevance of Cybernetics," Architectural Design, September Issue (1969): 494. interdisciplinary minds organised by Pask to assist in the development of Cedric Price's Fun Palace.

5 Quoted in Paul Brown et al eds, White Heat Cold Logic: British Computer Art 1960-1980 (Cambridge, MA: MIT Press, 2008), 37-51. 2007 from http://www.theage.com.au/articles/2005/05/09/1115584883777.html Ranulph Glanville,'Try again. Fail again. Fail better: The Cybernetics in Design and the Design in Cybernetics," Kybernetes 36: 9/10 (2007), 1199. Philip Ball, Shapes (Oxford: Oxford University Press, 2009).

Kepes, The Nature and Art of Motion, 6.

László Moholy-Nagy, Vision in Motion (Chicago, P Theobald, 1947), 42. MA: MIT Press, 2003), 128-32.

12 György Kepes, The Nature and Art of Motion, 6.

Brown, Paul, et al eds. White Heat Cold Logic: British Computer Art 1960-1980. Cambridge, MA: MIT Press, 2008.

Bunbury, Stephanie. "It's time to learn to love your Dalek." 10 May 2005, retrieved 10 September 2007 from http://www.theage.com.au/articles/2005/05/09/1115584883777.html Frazer, John. An Evolutionary Architecture. London: Architectural Association Publications, 1995.

Glanville, Ranulph. "Try again. Fail again. Fail better: The Cybernetics in Design and the Design in Cybernetics." Kybernetes 36: 9/10 (2007), 1199.

Kepes, György. The Nature and Art of Motion, George Braziller, 1993.

Moholy-Nagy, László. Vision in Motion. Chicago, P. Theobald, 1947.

Pask, Gordon. “A Comment, a Case History and a Plan” (1970) reprinted in J Reichardt ed, Cybernetic Art and Ideas. London: Studio Vista, 1971, 77.

Pask, Gordon. "The Architectural Relevance of Cybernetics," Architectural Design, September (1969): 494.

Wardrip-Fruin, Noah and Nick Montfort, eds. The New Media Reader. Cambridge, MA: MIT Press, 2003. 
Ako su računari nekada bili veličine objekata, objekti sada postaju računari sposobni da obavljaju I/O komunikacijske protokole ili programirani na molekularnom-nano nivou materijala, ili čak samostalno rade učenju genetskih algoritama.

Ako je javni prostor u kome danas živimo u osnovi izgrađen na početku industrijske revolucije, informacijsko društvo sada donosi nove principe i tehnologije preispitujuć funkcionalnost i strukturu ulica, avenija, trgova i infrastrukture grada.

KLJUČNE REČI: XXXXXXXXXXXXXX, XXXXXXXXXXXXX, XXXXXXXXXXXX, XXXXXXXX, XXXXXXXXXXXXXXXXXXXXXXXX,

\section{KONSTRUISANJE ADAPTIVNIH EKOLOGIJA: U PRAVCU BEHAVIORISTIČKOG MODELA ZA ARHITEKTURU}

\section{Theodore Spyropoulos}

György Kepes (Giorgi Kepes) je jednom objavio, 'U našim novim konceputualnim modelima prirode, stabilni, čvrsti svet materije, koji se u prošlosti smatrao trajnim i predodređenim, se shvata kao široko raspršena polja dinamičkih energija. Materija - opipljiva, vidljiva, stabilna supstanca u staroj slici fizičkog sveta - danas se preformuliše u jednu nevidljivu mrežu nukelarnih događaja sa elektronima koji kružeći putanjom skaču sa jedne na drugu orbitu." Fiksne i konačne tendencije koje su nekada služile da kategorišu prirodne i veštačke svetove su učinjene zastarelim.

Danas ukrštanja informacija, života i materije prikazuju složenosti koje sugerišu mogućnost mnogo dublje sinteze. U okviru tog konteksta, međutim, arhitektura je primorana da radikalno ponovo formuliše svoj odgovor na nove društvene i kulturne izazove i u jednom ubrzanom procesu urbanizacije. Arhitektura danas mora da učestvuje i da se bavi sredinama bogatim informacijama koje oblikuju naše živote konstruišući računarske okvire koji će omogućiti promene, prihvatajući zahtev za adaptativnim modelima života. Naš pristup rešavanja ovih izazova obuhvata istraživanje sistemskih formi interakcije koja se bavi behavioralnim svojstvima koja su poliskalarna, omogućavajući mreže biodiverziteta koje bi delovale između urbanih konteksta, zgrada I materijala. Jedna bliska korelacija materijala i računarskog sadejstva omogućava pojavu generativno vremenski zasnovanog behaviorističkog modela života, gde uzajamno dejstvo lokalnog posredovanja i podsticaja životne sredine izgrađuju kolektivna uređenja. Za razliku od većine veštačkih objekata, arhitekture ovih objekata nisu ugrađene u planovima, već su pre povezane radnje kojima se upravlja kroz nastajuću kolektivnu interakciju. 


\section{OBLICI ZASIĆENOSTI}

Diskretni i neprekidni događaji u arhitektonskom projektovanju

\section{Johan Bettum}

Ovaj esej se bavi mogućnostima i ograničenjima arhitektonskog projektovanja na spoju tehnologije i disciplinarno specifičnih razvoja u arhitekturi. Teoretski model koji se razvija sažima suštine toga šta znači raditi sa odnosnim digitalnim i analogim sistemima modeliranja. On predstavlja oslobađanje od neprekidne krize $\mathrm{u}$ arhitektonskom obrazovanju boreći se sa naletom digitalnog. Osim toga, on se bavi nekritičkom opsednutošću koju arhitektonska akademija ima $\mathrm{u}$ vezi sa tehnologijom bez zapadanja u različite oblike reakcionarnih praksi koje se trenuto pojavljuju u struci kao i u školama.

Diskusija se fokusira na sisteme i režime predstavljanja u arhitektonskom projektovanju i proizvodnji i problematizuje ulogu digitalnih i računarskih projektantskih postupaka u odnosu na analoge sistema predstavljanja, arhitektonske beskrajne izgradnje naše fizičke sredine i svojstvenih ograničenja digitalnih sistema s' obzirom na njihov 'racionalan' karakter.

Ovaj esej pokušava da se razreši uticaj i status digitalnog fokusiranjem na inkluzivni pojam prostora. To je i arhitektonski prostor ali isto tako i prostor produktivnog dizajniranja/projektovanja u kome arhitekte rade. Razvijajući ovaj argument, prodiskutovana su tri umetnička dela i početna pretpostavka za taj argument se zasniva na teoriji umetnosti.

KLJUČNE REČI: ANALOGI SISTEMI PREDSTAVLJANJA; DIGITALNI SISTEMI PREDSTAVLJANJA; DISKRETAN, NEPREKIDAN, INKLUZIVAN; ZASIĆENJE, UČESNIK.

\section{DIGITALNA GROTESKA - KA MIKRO-TEKTONSKOJ ARHITEKTURI}

\section{Michael Hansmeyer, Benjamin Dillenburger}

Računarski dizajn omogućava arhitekturu sa izuzetnim stepenom topografske i topološke složenosti. Ograničenja tradicionalnih CNC tehnologija su sve do nedavno sprečavale arhitekturu da bude fabrikovana. Iako je proizvodnja aditiva omogućila da se ovi složeni oblici materializuju, to je ostvareno samo u veoma maloj razmeri. U pokušaju da se proizvodnja aditiva primeni na konstrukcije arhitekture u punoj razmeri, nailazi se na dilemu: 